\title{
HUBUNGAN STRESS DENGAN GANGGUAN MENSTRUASI PADA REMAJA PUTRI
}

\author{
Is Susiloningtyas ${ }^{1)}$, Eka Fitriana Rahayu ${ }^{2)}$ \\ ${ }^{1,2)}$ Program Studi Kebidanan, Sarjana dan Pendidikan Profesi Bidan Fakultas Kedokteran Universitas Islam \\ Sultan Agung \\ $\underline{\text { issusiloningtiyas@gmail.com, ekafitrianarahayu@gmail.com }}$
}

\begin{abstract}
ABSTRAK
Beberapa Faktor dilihat dari segi psikologis yang dapat mempengaruhi serta mengakibatkan emosi remaja tidak stabil sehingga menyenbabkan stress. Stress pada remaja perempuan salah satunya dapat mengganggu siklus menstruasi. Tujuan penelitian Penelitian ini adalah untuk mengetahui hubungan stress dengan gangguan menstruasi pada remaja putru serta faktor penyebab - penyebabnya. Penelitian ini termasuk Penelitian systematic review yang berasal dari delapan penelitian terdahulu yang membahas tentang hubungan stress dengan gangguan menstruasi pada remaja putri $\mathrm{w}$ dengan cara mencari artikel di database yaitu PubMed, Science Direct, dan Google Scholar dengan rentang tahun 2015 - 2020. Kesimpulan pada penelitian ini menunjukkan bahwa Pada remaja putri, terdapat hubungan yang kuat antara tingkat stres dan perubahan pola menstruasi. Hal ini dikarenakan remaja mengalami peristiwa penting dalam hidup yang tidak terduga, seperti perceraian orang tua, putus cinta atau putus cinta, cinta bertepuk sebelah tangan, terlibat dalam kecelakaan dan faktor kadar hormon akibat stress serta emosi yang kurang stabil. Serta kemungkinan informasi yang diperoleh anak tidak akurat, baik itu dari media cetak, media elektronik, maupun pihak-pihak yang wajib memberikan penyuluhan.
\end{abstract}

Kata kunci : remaja putri, menstruasi, stress, psikologis

\section{PENDAHULUAN}

Remaja mengalami perubahan psikologis seperti emosi yang tidak stabil, yang dapat menyulitkan mereka untuk menghadapi dan memecahkan kesulitan. Remaja akan berjuang untuk memahami diri mereka sendiri jika keadaan emosi mereka terus berubah, yang mengarah ke jalan buntu. Stres akan terjadi jika situasi tersebut tidak ditangani dengan tepat. Penyakit reproduksi yang berhubungan dengan peristiwa menstruasi merupakan salah satu hal yang terjadi pada wanita yang sedang stres.Periode menstruasi tidak selalu dapat diprediksi. Beberapa penyebab mempengaruhi siklus menstruasi yang tidak teratur ini, termasuk variasi kadar hormon yang disebabkan oleh stres atau kondisi mental yang tidak stabil.Menurut (Rezki, Irmayanti, and Darwin 2019) Masa remaja atau sering dikenal dengan masa pubertas merupakan masa pertumbuhan fisik, biologis, psikologis, dan sosial yang pesat dalam kehidupan seseorang.

Menurut para ahli, pubertas mengacu pada perubahan biologis dan fisiologis yang terjadi secara cepat dari masa bayi hingga dewasa, khususnya perubahan pada organ reproduksi dan perubahan biologis yang terjadi pada remaja putri, salah satunya adalah dimulainya menstruasi. Sekitar 70-90 \% kasus nyeri haid,terjadi saat usia remaja dan dapat 
menimbulkan dampak konflik emosional, ketegangan dan kegelisahan. Dari konflik emosional, ketegangan dan kegelisahan akan mempengaruhi kecakapan dan keterampilannya. Siklus menstruasi merupakan siklus alami yang terjadi setiap bulan. terjadi pada wanita muda Menarche terjadi antara usia 12 dan 15 tahun, dan berlangsung selama 12 sampai 15 tahun. berlanjut hingga usia 45-50 tahun (menopause).

Berdasarkan penelitian yang dilakukan (Setiawati 2015), Pendarahan periodek ditentukan olehSejumlah faktor, termasuk kesehatan berat badan dan status gizi tubuh wanita, Menjadi salah satu Penyebab utama stres (ketegangan) serta masalah yang ada pada remaja berasal dari hubungan dengan teman dan keluarga, tekanan dan harapan dari diri sendiri dan orang lain, tekanan di sekolah dari guru dan pekerjaan rumah, tekanan ekonomi, dan tragedi dalam hidup mereka seperti kematian.Gangguan fungsi hormon, penyakit sistemik, stres, kelenjar gondok, dan hormon prolaktin yang tinggi semuanya mempengaruhi kelainan siklus menstruasi. Ada tiga jenis gangguan stres menstruasi: polimenore (siklus menstruasi pendek), oligomenore (siklus menstruasi memanjang), dan amenore (tidak menstruasi selama tiga bulan). Mengurangi stres melalui mekanisme koping yang baik, seperti diet dan nutrisi, istirahat dan tidur, olahraga, berhenti merokok, menghindari alkohol, mengontrol berat badan, mengatur waktu dengan tepat, terapi psikofarmasi, terapi somatik, dan terapi agama, semuanya digunakan untuk mencegah gangguan siklus menstruasi (Sitoayu, Pertiwi, and Mulyani 2017) .

Peristiwa dan pengalaman kehidupan biasa dapat menyebabkan seseorang menjadi stres. Stres membantu dalam stimulasi proses berpikir dan kemampuan individu untuk tetap sadar akan lingkungan mereka. Selain itu, stres mendorong perkembangan dan pertumbuhan kepribadian. Akan terjadi ketidakseimbangan ketika stres mengganggu kemampuan koping seseorang, yang pada akhirnya akan berujung pada krisis.

Penulis tertarik untuk melakukan literatur review "Hubungan antara Stres dan Gangguan Menstruasi pada Remaja Putri" berdasarkan uraian yang diberikan.

\section{METODE PENELITIAN}

Studi ini merupakan suatu tujuan (literatur review).Sumber data penelitian ini berasal dari literatur yang diperoleh melalui internet. Penelitian ini termasuk Penelitian systematic review yang berasal dari delapan penelitian terdahulu yang membahas tentang hubungan stress dengan gangguan menstruasi pada remaja putri $w$ dengan cara mencari artikel di database yaitu PubMed, Science Direct, dan Google Scholar dengan rentang tahun 2015 - 2020. Berikut metodologi pengumpulan data yang digunakan:

1. Sebelum analisis data dilaksanakan, terlebih dahulu dilakukan studi pustaka yang menjadi bahan pertimbangan dan tambahan wawasan 
untuk penulis mengenai lingkup kegiatan dan konsep-konsep yang tercakup dalam penulisan

2. Untuk melakukan pembahasan analisis dan sintesis data-data yang diperoleh, diperlukan data referensi yang digunakan sebagai acuan, dimana data tersebut dapat dikembangkan untuk dapat mencari kesatuan materi sehingga diperoleh suatu solusi dan kesimpulan.

Artikel penelitian yang berjudul “ Hubungan Stress Dengan Gangguan Menstruasi Pada Remaja Putri " penelitian yang dilakukan mengunakan populasi penelitian ini adalah semua remaja putri Sampel berjumlah 148 responden yang diambil berdasarkan Data dianalisis secara univariat dan bivariat dengan uji.

\section{HASIL \& PEMBAHASAN}

\section{A. HASIL}

Hasil penelitian dengan responden sebanyak 148 orang didapatkan rata-rata tengah umur responden yaitu 18 tahun, IMT didapatkan rata-rata nilai IMT sebesar 20.76,

Untuk tingkat stres remaja putri adalah tingkat stres sedang sebanyak 76 orang dengan presentase $(51,4 \%)$, tingkat stres kategori normal sebanyak 31 orang dengan persentase $(20,9)$, tingkat stres kategori ringan sebanyak 30 dengan presentase $(20,3 \%)$, dan tingkat stres berat sebanyak 11 orang dengan presentase $(7,4 \%)$.

Siklus menstruasi pada remaja putri yaitu kategori normal sebanyak 75 orang dengan presentase (50.7\%), kategori polimenorea sebanyak 54 orang dengan presentase $(36.5 \%)$ dan kategori oligomenorea sebanyak 19 orang dengan persentase (12.8\%)

Terdapat hubungan yang bermakna antara tingkat stres terhadap siklus menstruasi pada remaja putri Semarang dengan nilai $p$ value sebesar $0.000 \quad(\mathrm{p}<0,05)$ dengan nilai korelasi koefisien sebesar 0.622 .

\section{B. PEMBAHASAN}

\section{Hubungan Tingkat Strees dengan mentruasi pada Remaja Putri}

Stres adalah suatu kondisi yang ditimbulkan oleh interaksi antara manusia dengan lingkungannya yang menimbulkan persepsi adanya jarak antara tuntutan situasi dengan sumber daya biologis, psikologis, dan sistem sosial seseorang.Stres berdampak pada kelainan siklus menstruasi. Stres mempengaruhi elevasi tulang rawan basal dan mengurangi hormon luteinizing, menyebabkan perubahan sistemik dalam tubuh, terutama pada sistem saraf di hipotalamus, melalui perubahan prolaktin atau endogenopia (LH) (Wahyuni 2016).

Beberapa faktor yang mempengaruhi siklus menstruasi yang tidak teratur ini, antara lain perubahan hormonal yang disebabkan oleh stres dan ketidakstabilan mental. Selain itu, perubahan berat dalam jumlah aktivitas atau fluktuasi berat badan juga dapat menyebabkan ketidakteraturan siklus menstruasi. Itu penting karena stres mempengaruhi sistem tubuh, terutama sistem saraf di hipotalamus, melalui perubahan prolaktin atau endogenopiat, yang dapat menyebabkan peningkatan kortisol basal 
JURNAL SEHAT MASADA VOLUME XVI

dan penurunan hormon luteinizing hormone (LH), dan tingkat stres siswa dipengaruhi. dengan banyaknya tugas yang harus diselesaikan dan aktivitas fisik yang tinggi di dalam atau di luar kampus.

Mahasiswi yang mengalami stres menghasilkan gangguan hormonal, dan ada hubungan antara tingkat stres dengan siklus menstruasi.

Hormon Stimulasi Folikel dan Hormon Luteinizing Estrogen tidak akan menyebabkan pertumbuhan sel telur, dan jika itu terjadi, estrogen dan progesteron tidak akan dihasilkan, sehingga terjadi ketidak teraturan menstruasi (Toduho, Kundre, and Malara 2014) .

Istilah "perubahan pola menstruasi" mengacu pada berbagai penyebab yang mungkin terjadi dalam kehidupan seorang wanita, seperti masalah gizi, masalah metabolisme, tumor, infeksi penyakit, dan sebagainya.Berbagai perubahan emosi sebagai akibat dari stressor yang berhubungan dengan fluktuasi hormon sepanjang siklus menstruasi. Selama kehamilan, sebagian besar wanita mengalami berbagai perubahan dalam pola menstruasi mereka (Rezki et al. 2019).

Ketegangan dan stres hanya dapat ditemukan di lingkungan remaja, menurut . Masalah putus cinta dapat menyebabkan banyak stres, terutama ketika menghadapi ujian yang panjang, banyak tugas dari sekolah, lembaga, atau akademi pendidikan, serta tuntutan dari orang tua untuk mencapai prestasi atau nilai yang sangat baik, atau kelulusan

akademik, dan hubungan. yang tidak bekerja baik dalam keluarga maupun dalam lingkungan sosial.

Stres berdampak pada sistem neuroendokrinologi sebagai sistem yang berperan penting dalam reproduksi wanita dalam pengaruhnya terhadap pola menstruasi. Temuan penelitian dibagi menjadi dua kategori: tingkat stres dan perubahan siklus menstruasi. Salib meja sedang tren ke atas.

Berdasarkan (D 2018) Ada juga perubahan pola menstruasi saat tingkat stres sedang tinggi hal ini dikarenakan tingkat stres yang dialami oleh seseorang, khususnya remaja putri, akan membuat perubahan ritme hormonal, sehingga terjadi perubahan siklus menstruasi.

Faktor-Faktor yang Mempengaruhi Siklus

\section{Menstruasi Remaja Putri}

Tingkat stres seseorang dapat mempengaruhi siklus menstruasi setiap bulannya.Ketidakteraturan siklus menstruasi harus segera ditangani agar tidak terjadi berkepanjangan. Pada seseorang yang mengalami stres disarankan untuk mengurangi faktor yang dapat menyebabkan stres dengan cara mengontrol emosi. Dengan mengontrol emosi dapat mempengaruhi produksi hormon kortisol menjadi normal. Dengan begitu seseorang tidak akan mengalami stres dan akan mempengaruhi siklus menstruasinya menjadi teratur(Islamy and Farida 2019).

Siklus menstruasi dipengaruhi oleh hormonal.Terutama hormon estrogen dan progesteron, kedua hormon tersebut 
dikeluarkan secara siklik oleh ovarium pada masa reproduksi.Status gizi juga bersinergi dengan siklus menstruasi. Siklus ovulasi supaya dapat berlangsung normal dan teratur, tubuh memerlukan 22\% lemak dan IMT lebih dari $19 \mathrm{~kg} / \mathrm{m} 2$. Sel - sel lemak berfungsi untuk membantu memproduksi estrogen yang diperlukan bagi proses ovulasi dan berjalannya siklus menstruasi (Coad., 2007).

Polimenorea dan oligomenorea mengindikasikan adanya ketidaknormalandalam sistem metabolisme tubuh. Efek jangka panjangnya adalah susah untuk hamil. Jika terjadi siklus pendek, berisiko terjadi unovulasi sedangkan jika terjadi siklus panjang, mengindikasikan sel telur jarang diproduksi. Keduanya mengindikasikan gangguan kesuburan pada wanita (Atikah dan Misaroh., 2009).

\section{Tingkat Stress dengan Gangguan Menstruasi pada Remaja Putri}

Menstruasi adalah proses alamiah yang terjadi pada perempuan. Menstruasi merupakan perdarahan yang teratur dari terus sebagai tanda bahwa organ kandungan telah berfungsi matang. Umumnya, remaja yang mengalami menarche adalah pada usia 12 sampai dengan 16 tahun. Menstruasi yang terjadi pada perempuan biasanya mengalami gangguan. Hal ini dipengaruhi oleh beberapa faktor diantaranya adalah perubahan kadar hormon akibat stres atau dalam keadaan emosi yang kurang stabil.

\section{KESIMPULAN}

Berdasarkan beberapa penelitian yang telah penulis review Terdapat hubungan yang kuat antara tingkat stress pada perubahan pola menstruasi. Hal ini dikarenakan remaja mengalami peristiwa penting dalam hidup yang tidak terduga, seperti perceraian orang tua, putus cinta atau putus cinta, cinta bertepuk sebelah tangan, atau terlibat dalam kecelakaan.Dan kemungkinan informasi yang diperoleh anak tidak akurat, baik itu dari media cetak, media elektronik, maupun pihak-pihak yang wajib memberikan penyuluhan. Bukan hanya itu saja gangguan menstruasi pada remaja putri juga disebabkan oleh faktor kadar hormon akibat stress serta emosi yang kurang stabil.

\section{DAFTAR PUSATAKA}

Rezki, Nfn, Nfn Irmayanti, and Devi Darwin. "TINGKAT STRES DENGAN GANGGUAN MENSTRUASI PADA REMAJA PUTRI: STUDI CROSSECTIONAL." Jurnal Fenomena Kesehatan $2.1 \quad$ (2019): 243-251. https://stikeskjp-palopo.ejournal.id/JFK/article/view/89

Setiawati, Sugma Epri. "Pengaruh stres terhadap siklus menstruasi pada remaja." Jurnal Majority 4.1 (2015).http://juke.kedokteran.unila.ac.id/ index.php/majority/article/view/507

Sitoayu, Laras, Dewi Ayu Pertiwi, and Erry Yudhya Mulyani."Kecukupan zat gizi makro, status gizi, stres, dan siklus menstruasi pada remaja." Jurnal Gizi Klinik Indonesia 13.3 (2017): 121-128. https://journal.ugm.ac.id/jgki/article/vie $\underline{\mathrm{w} / 17867}$ 
Wahyuni, Sri. "Hubungan Stres dengan Gangguan Siklus Menstruasi Pada Tingkat 2 Prodi DIII Kebidanan STIKES Muhammadiyah Klaten." INVOLUSI Jurnal Ilmu Kebidanan 7.12

(2016).http://jurnal.stikesmukla.ac.id/ind ex.php/involusi/article/view/211

Toduho, Serly, Rina Kundre, and Reginus Malara."Hubungan Stres Psikologis dengan Siklus Menstruasi pada Siswi Kelas 1 Di SMA Negeri 3 Tidore Kepulauan." Jurnal Keperawatan 2.2 (2014).https://ejournal.unsrat.ac.id/index .php/jkp/article/view/5306

Rezki, Nfn, Nfn Irmayanti, and Devi Darwin. "TINGKAT STRES DENGAN GANGGUAN MENSTRUASI PADA REMAJA PUTRI: STUDI CROSSECTIONAL." Jurnal Fenomena Kesehatan $2.1 \quad$ (2019): 243251.https://stikeskjp-palopo.ejournal.id/JFK/article/view/89

Mutia, Oktaviani. HUBUNGAN TINGKAT STRES TERHADAP GANGGUAN SIKLUS MENSTRUASI PADA MAHASISWI FAKULTAS KEDOKTERAN UNIVERSITAS ANDALAS ANGKATAN 2017. Diss. Universitas Andalas, 2018.http://scholar.unand.ac.id/34809/

Aesthetics, Farida. Faktor-Faktor yang mempengaruhi siklus Menstruasi pada remaja tingkat remaja putri tingkatIII. Jurnal keperawatan jiwa Volume 7.Nomor 1(2019). https://jurnal.unimus.ac.id/index.php/JK J/article/view/459 